\title{
EFEKTIFITAS PEMBERIAN SOYGHURT TERHADAP PENURUNAN KADAR KOLESTEROL DALAM DARAHMENCIT (Mus musculus) DENGAN JUMLAH BAKTERI ASAM LAKTAT DAN SUHU INKUBASI YANG OPTIMUM
}

\author{
Rosmayani Hasibuan \\ Jurusan Analis Kesehatan Poltekkes Kemenkes Medan
}

\begin{abstract}
Abstrak
Penelitian tentang pembuatan soyghurt dengan menggunakan bakteri asam laktat, Lactobacillus bulgaricus dan Streptococcus thermophillus. Penelitian ini bertujuan untuk mengetahui efektifitas soyghurt dalam menurunkan kadar kolesterol dalam darah mencit dengan jumlah bakteri asam laktat dan suhu inkubasi yang optimum. Perlakuan suhu inkubasi pada pembuatan soyghurt adalah $30^{\circ}$, $35^{\circ}$, dan $40^{\circ} \mathrm{C}$. Analisa jumlah bakteri asam laktat berdasarkan Standar PlateCount.Identifikasi jenis bakteri dilakukan dengan pengamatan karakteristik morfologi dan uji biokimia.Karakteristik morfologi dilakukan dengan pewarnaan Gram, sedangkan uji biokimia dilakukan dengan uji katalase, fermentasi karbohidrat, motilitas, reduktase nitrat, dan uji ketahanan suhu. Hasil penelitian menunjukkan bahwa suhu yang optimal pada pembuatan soyghurt adalah $40^{\circ} \mathrm{C}$ dengan jumlah koloni sebesar 1,63 x $10^{9} \mathrm{CFU} / \mathrm{ml}$. Pemberian soyghurt dengan konsentrasi 0,25, 0,50 dan 1\% kepada hewan uji (mencit) menunjukkan pengaruh yang berbeda terhadap penurunan kadar kolesterol dalam darah mencit, masing-masing 18,43, 22,18 dan 35,75\%. Pemberian soyghurt dengan konsentrasi $1 \%$ menunjukkan penurunan kadar kolesterol yang paling significan yaitu $35,75 \%$.
\end{abstract}

Kata kunci : Suhu inkubasi, Bakteri asam laktat, Soyghurt, Kolesterol

\section{PENDAHULUAN}

\section{Latar Belakang Masalah}

Sejak abad II sebelum Masehi susu kedelai sudah dibuat di negara Cina, dan kemudian berkembang ke Jepang. Setelah Perang Dunia II baru berkembang ke Asia Tenggara. Sampai saat ini perkembangan susu kedelai di Indonesia masih jauh tertinggal dengan Singapura, Malaysia dan Philipina (Koswara, 2006).

Susu kedelai baru beberapa tahun terakhir dikenal dan dikembangkan di Indonesia. Seperti halnya susu sapi, susu kedelai ternyata dapat dibuat menjadi yoghurt susu kedelai yang dikenal dengan nama "Soyghurt", yang merupakan salah satu produk susu fermentasi yang dibuat dengan melibatkan bakteri asam laktat seperti penambahan bakteri Streptococcus thermophillus dan Lactobacillus bulgaricus (Heller, 2001).

Produk soyghurt yang berkualitas memerlukan kombinasi dua atau lebih bakteri yang digunakan sebagai starter. Kombinasi kedua bakteri asam laktat tersebut bersifat sinergis, Pada awal pertumbuhan S. thermophilus akan menghasilkan kadar asam laktat 0,8-1,0\%, dan kondisi ini dimanfaatkan oleh $L$. bulgaricus hingga mencapai kadar asam laktat 1,5-2,0\%. (Soeharsono, 2010). Tingkat penambahan dan kondisi starter berpengaruh terhadap aktifitas bakteri dan produk asam yang dihasilkan (Buckle et al., 1987), selain itu harus diperhatikan penggunaan suhu inkubasi agar aktifitas bakteri starter berlangsung secara optimal (Soeharsono, 2010).

Kesadaran konsumen untuk mengkonsumsi makanan sehat (pangan fungsional) semakin meningkat sehingga produk hasil fermentasi yang aman dikonsumsi juga cenderung meningkat. Produk-produk fermentasi telah lama diketahui mempunyai berbagai keunggulan ditinjau dari aspek gizi dan kesehatan.

Peningkatan pendapatan masyarakat dan kebutuhan makanan sehat yang terus berkembang menunjukkan besarnya peluang untuk malakukan penelitian tentang pangan fungsional diantaranya adalah susu fermentasi (Kurana, 2007). Dalam pembuatan soyghurt digunakan 2 spesies bakteri yang tumbuh secara simbiotik yaitu Lactobacillus bulgaricus dan Streptococcus thermophillus. Kedua spesies bakteri ini jika ditumbuhkan bersama sama akan memproduksi asam lebih banyak dibandingkan jika tumbuh secara terpisah. L. bulgaricus dan S. thermophillus merupakan bakteri asam laktat homofermentatif yang terutama merubah laktosa menjadi asam laktat. Suhu inkubasi biasanya diantara $40-45^{\circ} \mathrm{C}$, $32^{\circ} \mathrm{C}$ atau pada suhu ruang (sekitar $29^{\circ} \mathrm{C}$ ) dengan waktu yang berbeda. Pada mulanya Lactobacilli tumbuh dominan dan menghasilkan asam amino glisin dan histidin, kedua senyawa ini akan merangsang pertumbuhan Streptococci (Hidayat,dkk, 2006) 
Pengaruh suhu inkubasi dengan modifikasi beberapa tingkatan suhu pada proses pembuatan soyghurt sangat menentukan populasi bakteri asam laktat dan komponen metabolit skunder yang dihasilkan sehingga perlu dilakukan penelitian tentang perbedaan suhu inkubasi terhadap jumlah koloni bakteri starter terutama $L$. bulgaricus dan $S$. thermophilus pada pembuatan soyghurt dan efektifitasnya terhadap penurunan kadar kolesterol di dalam darah.

\section{Pembatasan dan Perumusan Masalah}

Penelitian tentang pengaruh suhu inkubasi terhadap jumlah koloni bakteri asam laktat yang digunakan sebagai starter sangat menentukan keberadaan bakteri $L$. bulgaricusdanS. thermophilus yangdidasarkan pada pertimbangan bahwa keduabakteri tersebut merupakan masalah utama padaproses pembuatan soyghurt. Suhu inkubasi yang sesuai akan memberikan pertumbuhan bakteri tersebut lebih optimum dan dapat efektif untuk menurunkan kadar koleterol di dalam darah.Bakteri asam laktat memiliki kemampuan menurunkan kolesterol di dalam darah sebagai salah satu unsur utama pada proses pembuatan soyghurt.Berdasarkan uraian di atas dapatdirumuskan beberapa permasalahan yaitu

1. Apakah perbedaan suhu inkubasi pada proses pembuatan soyghurt dapat menghasilkan jumlah koloni bakteri asam laktat yang bervariasi.

2. Apakah bakteri asam laktat pada soyghurt memiliki potensi dalam menurunkan kadar kolesterol dalam darah

\section{Kerangka Pemikiran}

Bakteri asam laktat L. bulgaricus dan $S$. thermophilus sebagai starter yang ditambahkan pada pembuatan soyghurt akan mampu mengikat atau memasukkan kolesterol ke dalam membran sitoplasmanya sehingga kadar kolesterol berada sesuai dengan kebutuhan metabolisme dalam tubuh. (Danielson et al., 1989)

Pertumbuhan bakteri asam laktat pada fermentasi soyghurt sangat dipengaruhi oleh suhu inkubasi, sehingga perlu dilakukan penggunaan suhu inkubasi yang berbeda untuk melihat seberapa banyak jumlah koloni $L$. bulgaricus dan $S$. thermophillus pada pembuatan soyghurt sehingga penurunan kadar kolesterol dapat terlihat nyata.

Pengaruh suhu inkubasi terhadap jumlah koloni bakteri asam laktat pada pembuatan soyghurt belum banyak dilaporkan, berdasarkan hal tersebut akan dilakukan penelitian tentang efektifitas pemberian soyghurt terhadap penurunan kadar kolesterol dalam darah dengan jumlah koloni BAL dan suhu inkubasi yang optimum.

\section{Tujuan Penelitian}

Penelitian ini bertujuan untuk:

1. Mendapatkan suhu inkubasi yang optimum bagi pertumbuhan L. bulgaricus dan S. thermophillus pada pembuatan soyghurt.

2. Menentukan jumlah koloni yang optimum dari $L$. bulgaricus dan $S$. thermophillus sebagai bakteri asam laktat pada pembuatan soyghurt.
3. Mengevaluasi kemampuan bakteri L. bulgaricus dan $S$. thermophillus dalam menurunkan kadar kolesterol di dalam darah secara in Vivo.

\section{Manfaat Penelitian}

Penelitian ini diharapkan dapat memberikan informasi tentang pengaruh suhu inkubasi pada pembuatan soyghurt terhadap jumlah koloni bakteri starter $L$. bulgaricus dan $S$. thermophillus yang memiliki kemampuan dalam menurunkan kadar koleterol di dalam darah sehingga dapat memberikan kontribusi bagi masyarakat dan industri yang bergerak di bidang pangan fungsional.

\section{Hipotesis}

Hipotesis dari penelitian ini adalah :

1. Dihasilkan suhu inkubasi yang sesuai untuk pertumbuhan bakteri asam laktat selama fermentasi pada pembuatan soyghurt.

2. Diperoleh jumlah bakteri asam laktat yang optimum untuk pembuatan soyghurt.

3. Bakteri asam laktat L. bulgaricus dan $S$. thermophillus mampu menurunkan kadar kolesterol di dalam darah.

\section{BAHAN DAN METODE}

\section{Waktu dan tempat}

Penelitian dilaksanakan pada bulan April hingga Juni 2012. Penelitian dilaksanakan di Laboratorium Teknologi Hasil Pangan Fakultas Pertanian Universitas Sumatera Utara, Laboratorium Mikrobiologi dan Laboratorium Kimia Klinik Balai Laboratorium Kesehatan Medan, Laboratorium Struktur Hewan Fakultas Matematika dan Ilmu Pengetahuan Alam, Universitas Sumatera Utara.

\section{Populasi dan Sampel Populasi \\ Populasi dalam penelitian ini adalah mencit (Mus musculus)}

\section{Sampel}

Sampel penelitian terdiri dari 40 ekor mencit berusia 2-3 bulan dengan berat 20 - 35 gram yang diperoleh dari Laboratorium Fisiologi Hewan FMIPA USU Medan.

\section{Alat dan Bahan \\ Alat}

Alat yang digunakan adalah kandang mencit, tempat makanan dan minuman, gavage, dissecting set, neraca balance, oven (Memmert), tabung reaksi, pipet takar, cawan petri, object glass, labu Erlenmeyer, lampu Bunsen, incubator (Memmert), autoklaf (Memmert), mikroskop (Olympus), dandang, blender (Miyako), kain saring, thermometer, gelas kimia, spuit, water bath (Memmert), sentrifuge (Memmert), Microlab 300 (EMerk). 


\section{Bahan}

Bahan yang digunakan untuk makanan mencit adalah ransum makanan mencit (B103) yang diproduksi oleh PT.Mabar Feed Indonesia.

Bahan yang digunakan untuk pakan kolesterol adalah ransum makanan mencit (B 103) yang mengandung minyak makan, kuning telur dan lemak kambing.

Bahan yang digunakan untuk pembuatan soyghurt adalah kedelai, susu skim, gula pasir, natrium bikarbonat, yoghurt plain (Biokul) yang mengandung bakteri L. bulgaricus dan S. thermophillus'

Bahan yang digunakan untuk pembiakan dan identifikasi Bakteri asam laktat adalah MRS Agar, $\mathrm{NaCl}$ fisiologis, alkohol, iodine, safranin, glukosa, laktosa ,maltosa, mannose, perhidrol.

Bahan yang digunakan untuk analisa kadar kolesterol adalah serum mencit, Kit Cholesterol (CE. Dialab) ), heparin (E.Merck).

\section{Pembuatan Kultur Starter (Koswara, 2006)}

Kultur starter dibuat dari susu bubuk yang ditambah air masak hingga mencapai total solid $16 \%$, kemudian dipanaskan $80^{\circ} \mathrm{C}$ selama 30 menit, dan ditambahkan gula pasir $2 \%$ kemudian diinokulasi dengan kultur starter dari Biokul sebanyak 5\%, kocok dan diinkubasi pada suhu 37 sampai $40^{\circ} \mathrm{C}$ selama 6 sampai 8 jam (Koswara, 2006).

\section{Pembuatan Susu Kedelai (Yudhi, 2008)}

1. Pembersihan dan Pencucian Biji kedelai dibersihkan dari kotoran (pasir), biji hitam dan berkapang, kemudian dicuci sampai bersih, kotoran dan biji yang mengapung dibuang. Pencucian dilakukan sampai air bilasan tampak jernih.

2. Perendaman

Biji kedelai yang telah dicuci direndam selama 8 jam dalam air yang mengandung $\mathrm{NaHCO}_{3} 0.5 \%$.Air diganti setiap 2-3 jam, setelah itu ditiriskan.

3. Perebusan

Biji kedelai dimasukkan kedalam air mendidih. Besar api diatur sehingga suhu bertahan antara $85-90^{\circ} \mathrm{C}$. Perendaman dalam air panas ini berlangsung selama 30 menit, setelah itu kedelai diangkat dan ditiriskan,kemudian kupas kulit kacang kedelai.

4. Persiapan Air Panas

Air bersih dipanaskan sampai suhu $90^{\circ} \mathrm{C}$.Jumlah air 6 kali berat kedelai kering.Suhu air dipertahankan selama pekerjaan berlangsung.

5. Penggilingan

Biji kedelai diblender sampai menjadi bubur kedelai.Penggilingan dilakukan sambil ditambah air panas.Jika air panas yang disediakan tidak habis untuk menggiling kedelai, sisa air dicampurkan kedalam bubur kedelai kemudian diaduk selama 3 menit.

6. Penyaringan

Bubur kedelai disaring dan diperas dengan kain saring rangkap dua,filtrat ditampung dan ampasnya dibuang. Filtrat dipanaskan $80-90^{\circ} \mathrm{C}$ selama 30 menit, kemudian dinginkan sampai $40^{\circ} \mathrm{C}$

\section{Pembuatan Soyghurt (Koswara, 2006)}

Susu kedelai hangat $\left(40^{\circ} \mathrm{C}\right)$ dicampur dengan susu bubuk hingga mencapai total solid $16 \%$, ditambahkan gula pasir 2\%, dan diinokulasikan dengan kultur starter 2-3\% (Yudhi, 2008). Kemudian dilakukan pengadukan sampai gumpalan starter larut semua dan dimasukkan kedalam wadah tertutup yang berpori, dibagi 3 tempat kemudian masing-masing wadah diinkubasi pada suhu $30^{\circ} \mathrm{C}$ (wadah I), $35^{\circ} \mathrm{C}$ (wadah II) dan $40^{\circ} \mathrm{C}$ (wadah III) selama 5 jam. Diagram alir pembuatan soyghurt dapat dilihat pada Lampiran E.

\section{Pemeliharaan Hewan Percobaan}

Penelitian ini menggunakan mencit (Mus musculus. L) jantan yang sehat sebanyak 40 ekor serta berumur 8-11 minggu dengan berat 20-35 gram. Mencit tersebut diperoleh dari Laboratorium Fisiologi Hewan FMIPA Universitas Sumatera Utara Medan dan dibagi dalam kelompok kontrol negatif, kontrol positif dan perlakuan.Mencit diberi makan dan minum secara oral. Kandang mencit dijaga kebersihannya dan cahaya ruangan dikontrol dan diatur 12 jam terang dan 12 jam gelap, sedangkan suhu dan kelembapan ruangan dibiarkan berada pada keadaan alamiah (Kusumawati, 2008).

\section{Perhitungan Jumlah Koloni Bakteri Asam Laktat (Suriawiria, 2006)}

Perhitungan jumlah koloni bakteri starter dengan metoda Total Plate Count dan seri pengenceran. Dipipet $1 \mathrm{ml}$ soyghurt (dari masing-masing wadah) dimasukkan ke dalam tabung reaksi, kemudian ditambahkan $9 \mathrm{ml}$ larutan $\mathrm{NaCl}$ fisiologis.Larutan ini merupakan larutan pengenceran $10^{-1}$. Dikocok sampai homogen, dilakukan pengenceran berikutnya hingga $10^{-10}$. Dari setiap pengenceran dipipet $1 \mathrm{ml}$ dimasukkan kedalam cawan petri yang sudah berisi media MRS Agar (Zahoor et al., 2003).. Disebarkan inokulum diatas permukaan media hingga merata. Inkubasi media MRS Agar yang sudah berisi suspensi soyghurt pada $37^{\circ} \mathrm{C}$ selama 72 jam dalam suasana fakultatif anaerob. Dihitung jumlah koloni dengan metode Total Plate Count.Cara pengenceran seri dapat dilihat pada Gambar 3.1.

Identifikasi Bakteri Asam laktat (Soeharsono. 2010) Isolat yang diperoleh dilakukan identifikasi berdasarkan karakteristik morfologi koloni dan reaksi biokimia. Uji yang digunakan adalah total bakteri asam laktat pewarnaan gram, uji katalase, uji motilitas, uji ketahanan suhu, uji reduktase nitrat dan fermentasi gula 
yang terdiri dari glukosa, laktosa, galaktosa dan mannosa (Soeharsono, 2010 ).

Pewarnaan gram menurut Hadioetomo (1985), dilakukan dengan membuat preparat ulas pada gelas benda, difiksasi di atas api bunsen. Setelah diberi pewarnaan preparat diamati dengan mikroskop, uji gram positif jika sel berwarna ungu dan negative jika sel berwarna merah.

Uji katalase menurut Lay (1994), dilakukan dengan mengambil isolat dari agar miring satu ose, kemudian dioleskan pada gelas benda yang telah diberi alkohol. Gelas benda ditetesi dengan larutan $\mathrm{H}_{2} \mathrm{O}_{2}$ 3\%.Diamati terbentuknya gelembung gas pada preparat. Jika terdapat gelembung gas berarti uji katalase tersebut positif

Uji fermentasi gula yang terdiri dari media glukosa, laktosa, galaktosa dan mannosa dilakukan dengan mengambil isolat dari agar miring dan dimasukkan kedalam masing-masing karbohidrat yang sebelumnya ditambahkan BCP (Brom Cresol Purple) sebagai indikator asam, kemudian diinkubasi pada suhu $37^{\circ} \mathrm{C}$ selama 48 jam (Hadioetomo.1985). Diamati perubahan warnanya, positif jika larutan berwarna kuning menandakan terjadinya proses fermentasi dan negatif jika larutan tetap berwarna ungu. (Garner dan Muriana, 1993).

Uji motilitas menurut Barrow dan Kromosom (1993) dilakukan dengan mengambil isolat dari agar miring dan ditusukkan pada agar tegak smi solid SIMA (Sulfit Indol Motility Agar), kemudian diinkubasi pada suhu $30^{\circ} \mathrm{C}$ selama 48 jam. Uji motilitas positif, jika pertumbuhan koloni menyebar luas pada agar dan negative jika pertumbuhan koloni tidak menyebar ( Hasan, 2006 ).

Uji ketahanan suhu (Stamer, 1979). Isolat dari agar miring dilarutkan ke dalam dua media MRS Broth dan diinkubasi pada suhu $10^{\circ} \mathrm{C}$ dan $45^{\circ} \mathrm{C}$ selama 48 jam. Jika media keruh menandakan adanya pertumbuhan bakteri.

Uji reduktase nitrat (Hadioetomo, 1993). Isolat dari agar miring dimasukkan ke dalam media Nitrat Broth, kemudian diinkubasikan pada suhu $37^{\circ} \mathrm{C}$ selam 48 jam,lalu ditetesi dengan $1 \mathrm{ml}$ Reagensia A (asam sulfanilat 0,8 gram dan $5 \mathrm{~N}$ asam asetat $100 \mathrm{ml}$ ) dan 1 $\mathrm{ml}$ Reagensia B (dimethyl- $\alpha$-naphtylamin 0,5 gram dan $5 \mathrm{~N}$ asam asetat $100 \mathrm{ml}$ ).Uji reduktase positif jika terbentuk warna merah, dan negatif jika tidak terjadi perubahan warna.

\section{Tahap Evaluasi Efek Bakteri Asam Laktat Secara} In Vivo (Djide, 2006)

Soyghurt yang mengandung jumlah bakteri asam laktat paling banyak dari ketiga perlakuan suhu inkubasi $\left(40{ }^{0} \mathrm{C}\right)$ diberikan kepada hewan uji mencit putih jantan.Mencit jantan sebagai bahan percobaan terdiri atas 5 kelompok perlakuan yaitu:

1. Kelompok kontrol negatif terdiri dari 8 ekor mencit jantan yang diberi makanan dan minuman biasa secara oral selama 2 minggu.
2. Kelompok kontrol positif terdiri dari 8 ekor mencit jantan yang diberi makanan biasa dan pakan kolesterol secara oral selama 2 minggu.

3. Kelompok perlakuan 1 terdiri dari 8 ekor mencit jantan yang diberi makanan biasa ditambah pakan kolesterol secara oral selama 2 minggu, kemudian diberikan soyghurt $0,25 \%$ secara oral selama 2 minggu.

4. Kelompok perlakuan 2 terdiri 8 ekor mencit jantan yang diberi makanan biasa ditambah pakan kolesterol secara oral selama 2 minggu, kemudian diberi kan soyghurt $0,5 \%$ secara oral selama 2 minggu.

5. Kelompok perlakuan 3 terdiri dari 8 ekor mencit jantan yang diberi makanan biasa ditambah pakan kolesterol secara oral selama 2 minggu, kemudian diberikan soyghurt $1 \%$ secara oral selama 2 minggu.

\section{Waktu Pengambilan Darah dan Pengukuran Kadar Kolesterol}

Pengambilan darah mencit untuk pengukuran kadar kolesterol adalah sebagai berikut :

1. Diukur kadar kolesterol total awal untuk mencit kontrol yang sebelumnya dipuasakan selama 18 jam.

2. Setelah 2 minggu, diukur kadar kolesterol dari kelompok kontrol positif yang sebelumnya dipuasakan selama 18 jam.

3. Setelah 4 minggu diukur kadar kolesterol dari kelompok perlakuan I,II dan III yang sebelumnya dipuasakan selama 18 jam.

\section{Cara Memperoleh Serum (Animal Research, 2002)}

Serum diperoleh dari darah mencit yang diambil melalui jantung menggunakan spuit sebanyak $1 \mathrm{ml}$ yang sudah mengandung heparin.

\section{Cara Pengukuran Kadar Kolesterol Metode CHOD.PAP (CE. Dialab)}

Kadar kolesterol diukur menggunakan Kit kolesterol dari CE.Dialab (Dialab Production Und Vertrieb Von Chemich-Technischen Produkten undLaborinstrumenten Geselsschaft m.b.H) metode CHOD.PAP menggunakan Microlab 300 (E-Merk) dengan cara kerja sbb :

\section{Standar}

Kedalam cuvet dipipet $10 \mu \mathrm{l}$ larutan standar kolesterol, kemudian ditambahkan reagensia kolesterol $1000 \mu \mathrm{l}$, dicampur dan diinkubasi pada suhu $37^{\circ} \mathrm{C}$ selam 5 menit.

2. Sampel

Kedalam cuvet dipipet $10 \mu \mathrm{l}$ serum kemudian ditambah reagensia kolesterol $1000 \mu \mathrm{l}$, dicampur dan diinkubasikan pada suhu $37^{\circ} \mathrm{C}$ selama 5 menit.

3. Blanko

Kedalam cuvet dipipet $1000 \mu \mathrm{l}$ reagensia kolesterol dan diinkubasikan pada $37^{\circ} \mathrm{C}$ selama 5 menit. Absorbans standar dan 
sampel diukur terhadap blanko dengan panjang gelombang $546 \mathrm{~nm}$.

\section{HASIL DAN PEMBAHASAN}

\section{Jumlah Koloni Bakteri Asam Laktat (BAL) Pada Soyghurt}

Jumlah koloni BAL menunjukkan angka yang bervariasi pada ketiga suhu inkubasi yang berbeda, yaitu pada suhu $30^{\circ}, 35^{\circ} \mathrm{C}$ dan $40^{\circ} \mathrm{C}$ seperti yang ditampilkan pada Tabel 4.1

Tabel 4.1. Jumlah Koloni Bakteri Asam Laktat pada Soyghurt SuhuInkubasi $30^{\circ}, 3^{\circ}$ dan $40^{\circ} \mathrm{C}$

\begin{tabular}{lcccccccccc}
\hline Suhu & $10^{-1}$ & $10^{-2}$ & $10^{-3}$ & $10^{-4}$ & $10^{-5}$ & $10^{-6}$ & $10^{-7}$ & $10^{-8}$ & $10^{-9}$ & $10^{-10}$ \\
\hline $30^{\circ} \mathrm{C}$ & 148 & 102 & 95 & 50 & 27 & 9 & 1 & - & - & - \\
$35^{0} \mathrm{C}$ & 263 & 160 & 121 & 94 & 54 & 20 & 8 & - & - & - \\
$40^{\circ} \mathrm{C}$ & $\sim$ & $\sim$ & $\sim$ & $\sim$ & $\sim$ & $\sim$ & 163 & 64 & 18 & 3 \\
\hline
\end{tabular}

BAL yang optimal yaitu sebesar 163 koloni pada pengenceran $10^{-7}$. Pada kondisi yang sama koloni BAL tidak dapat dihitung dari pengenceran $10^{-1} \mathrm{~s} / \mathrm{d} 10^{-6}$. Hal ini disebabkan karena pertumbuhan koloni Streptococcus thermophillus yang sangat mendominasi dan tumbuh hampir diseluruh permukaan di dalam cawan petri. $S$. thermophillus berkembang lebih cepat mengawali pembentukan asam laktat melalui fermentasi laktosa. Pertumbuhan ini terus berlangsung sampai mencapai $\mathrm{pH}$ 5,5 ( Lyn et al., 2010). Kondisi ini memberikan lingkungan yang sangat baik untuk pertumbuhan L. bulgaricus (Sneath et al., 1986).

Jumlah koloni kedua bakteri ini pada pengenceran $10^{-7}$ dapat dilihat pada Tabel 4.2.

Tabel 4.2. Jumlah Koloni Lactobacillus bulgaricus dan Streptococcus Pengenceran $10^{-7}$ thermophillus pada

\begin{tabular}{lcccc}
\hline \multirow{2}{*}{ Jenis Koloni } & \multicolumn{4}{c}{ Jumlah koloni (CFU/ml) tiap ulangan } \\
& 1 & 2 & 3 & Rata-rata \\
\hline Lactobacillus bulgaricus & 35 & 33 & 37 & 35 \\
$\begin{array}{l}\text { Streptococcus } \\
\text { thermophillus }\end{array}$ & 128 & 125 & 128 & 127 \\
\hline
\end{tabular}

Malaka (2005) melaporkan bahwa pertumbuhan Lactobacillus bulgaricus optimum pada suhu $37^{\circ} \mathrm{C}$ pada waktu inkubasi 14 jam, menghasilkan jumlah koloni sebesar $4,9 \times 10^{9} \mathrm{CFU} / \mathrm{ml}$, sedangkan pada suhu $25^{\circ} \mathrm{C}$ dan $30^{\circ} \mathrm{C}$ selama 6 jam masih menunjukkan fase pertumbuhan adaptasi (fase lag). Pertumbuhan yang thermofilik tersebut ternyata dapat pula dirangsang oleh natrium format yang dibebaskan dari laktosa selama pemanasan. Hal ini sesuai dengan pernyataan Herawati dan Andang (2009) bahwa format dan $\mathrm{CO}_{2}$ yang dihasilkan akan menstimulasi Lactobacillus bulgaricus, disamping itu aktifitas proteolitik dari $L$. bulgaricus ternyata menghasilkan peptide dan asam amino yang digunakan untuk pertumbuhan Streprococcus thermophillus. Pette dan Lolkema dalam Soeharsono (2010), menyatakan bahwa jumlah sel dari kultur campuran Lactobacillus bulgaricus dan Streptococcus thermophillus pada suhu inkubasi $45^{\circ} \mathrm{C}$ selama 3 jam menghasilkan jumlah Streptococcus thermophillus yang lebih besar yaitu 88 x $10^{7} \mathrm{CFU} / \mathrm{ml}$, sedangkan Lactobacillus bulgaricus sebesar 17 x $10^{7} \mathrm{CFU} / \mathrm{ml}$.

Demikan juga dengan hasil penelitian yang dilaporkan oleh Lyn et al (2010), dengan menggunakan campuran Lactobacillus bulgaricus dan Streptococcus thermophillus pada suhu $37^{\circ}, 42^{0}$ dan $45^{\circ} \mathrm{C}$, Streptococcus thermophillus tumbuh $93 \%$ lebih banyak pada masing masing suhu tersebut dibandingkan dengan Lactobacillus bulgaricus, sedangkan pada penelitian ini dengan menggunakan suhu $40^{\circ} \mathrm{C}$ menunjukkan jumlah $S$. thermophillus 38\% lebih banyak dari L. bulgaricus.

Berdasarkan dari hasil perhitungan jumlah koloni BAL pada penelitian ini diperoleh bahwa soyghurt dengan suhu inkubasi $40^{\circ} \mathrm{C}$ mengandung BAL sebesar $1,63 \times 10^{9}$ $\mathrm{CFU} / \mathrm{ml}$. Hasil ini sesuai dengan jumlah BAL dalam usus yang dibutuhkan untuk penurunan kadar kolesterol yaitu sebesar $10^{8}-10^{11}$ CFU/ml (Jawetz, 1980), dan menurut Wood (2002) jumlah minimal sel aktif dalam bahan pangan probiotik adalah $10^{6} \mathrm{CFU} / \mathrm{ml}$. Pierre et al. (2000) juga melaporkan bahwa jumlah bakteri probiotik $>1 \times 10^{8}$ CFU/g dalam makanan yang dikonsumsi akan memberikan pengaruh proses metabolisme di dalam usus, antara lain mengubah $\mathrm{pH}$ lambung dan meningkatkan populasi bakteri.

\section{Identifikasi Bakteri Asam Laktat}

Identifikasi BAL dilakukan dengan uji karakteristik dan morfologi serta uji biokimia antara lain adalah uji katalase, reduktase nitrat, motilitas, ketahanan suhu dan uji fermentasi karbohidrat. Hasil identifikasi BAL dapat dilihat pada Tabel 4.3

Tabel 4.3. Karakteristik Morfologi Sel dan Uji Biokimia BAL

\begin{tabular}{lll}
\hline Karakteristik & BAL $\mathbf{~}$ & BAL 2 \\
\hline Bentuk sel & Batang & Coccus \\
Pemetaan & Rantai pendek & Rantai panjang \\
Pewarnaan gram & Positif & Positif \\
Katalase & Negatif & negatif \\
Fermentasi & Mampu memfermentasi & Mampumemfermentas \\
& Karbohidrat & karbohidrat \\
Motilitas & Negatif & Negatif \\
Reduktase nitrat & Negatif & Negatif \\
Ketahanan suhu & Tidak tumbuh pada suhu & Tidak tumbuh pada suhu \\
& $10^{\circ} \mathrm{C}$, tumbuh pada $45^{\circ} \mathrm{C}$ & $10^{\circ} \mathrm{C}$,tumbuh pada $45^{\circ} \mathrm{C}$ \\
\hline
\end{tabular}




\section{Pengukuran Berat Badan Mencit}

Berat badan hewan uji (mencit) diukur pada 0 hari, 15 hari dan 30 hari pada masing-masing kelompok perlakuan. Pada kelompok 0 hari mencit hanya diberikan pakan standar selama aklimatisasi. Selanjutnya pada hari 0 s/d hari ke 15, kepada 4 kelompok lainnya (Kontrol positif, P1, P2 dan P3) diberikan pakan kolesterol tinggi yang mengandung lemak kambing $10 \%$, kuning telur $5 \%$, dan minyak makan $1 \%$ selama 2 minggu.

Tabel 4. 4. Persentase Penambahan Berat Badan Mencit pada Hari Ke 15 Masing Masing Perlakuan

\begin{tabular}{llccc}
\hline Perlakuan & $\begin{array}{l}\text { Berat } \\
\text { Badan } \\
\text { Awal } \\
\text { Pada }\end{array}$ & $\begin{array}{l}\text { Berat } \\
\text { Badan } \\
\text { Hari Ke(g) }\end{array}$ & $\begin{array}{l}\text { Penambahan } \\
\text { Berat }\end{array}$ & $\begin{array}{c}\text { Penambahan } \\
\text { BadanBerat Badan } \\
\text { ( \% ) }\end{array}$ \\
& Hari (g) $(\mathbf{g})$ & & \\
\hline Kontrol - & 31,11 & 32,75 & 1,64 & $5,27^{\mathrm{a}}$ \\
Kontrol + & 33,07 & 35,05 & 1,98 & $5,99^{\mathrm{b}}$ \\
Perlakuan 1 & 32,72 & 35,85 & 3,13 & $9,57^{\mathrm{c}}$ \\
Perlakuan 2 & 32,76 & 35,62 & 2,86 & $8,73^{\mathrm{c}}$ \\
Perlakuan 3 & 32,65 & 35,33 & 2,68 & $8,21^{\text {bc }}$ \\
\hline
\end{tabular}

Keterangan : notasi huruf yang berbeda menunjukkan beda nyata pada taraf $5 \%$

Kelompok Kontrol positif menunjukkan persentase penambahan berat badan yang berbeda nyata dengan kelompok perlakuan P1, P2 dan P3. Kelompok P1 memberikan persentase penambahan berat badan yang berbeda tidak nyata terhadap kelompok P2 dan P3, demikian juga kelompok perlakuan P2 memberikan persentase penambahan berat badan yang berbeda tidak nyata terhadap kelompok P3.

Hasil penelitian ini menunjukkan bahwa pemberian pakan kolesterol 2,5 gr/hari selama 2 minggu pada perlakuan (Kontrol positif, P1, P2, P3) memberikan persentase penambahan berat badan mencit yang terendah sebesar 5,99\% dan yang tertinggi sebesar $9,57 \%$. Selanjutnya pada hari ke 15 s/d hari ke 30, kepada hewan uji kelompok P1diberikan soyghurt sebanyak 0,25\%, kelompok P2 0,5\%, dan untuk kelompok P3 sebanyak $1 \%$. Pada kelompok hari ke 30 ini, tidak terjadi penurunan berat badan mencit pada kelompok kontol negatif dan kontrol positif, akan tetapi terjadi penurunan berat badan hewan uji terhadap kelompok Perlakuan P1, P2, dan P3.

Berdasarkan uji statistik persentase penurunan berat badan mencit pada hari ke 30, kelompok P1 menunjukkan persentase penurunan berat badan yang berbeda nyata $(\mathrm{P}<0,05)$ dengan kelompok $\mathrm{P} 2$ dan $\mathrm{P} 3$. Kelompok P2 menunjukkan persentase penurunan berat badan yang berbeda nyata $(\mathrm{P}<0,05)$ dengan kelompok $\mathrm{P} 3$. Untuk lebih jelasnya dapat dilihat pada Tabel 4.5.
Tabel 4.5. Persentase Penurunan Berat Badan Mencit pada Hari ke 30 Masing-Masing Kelompok Perlakuan

\begin{tabular}{lcccc}
\hline Perlakuan & $\begin{array}{c}\text { Berat } \\
\text { Badan } \\
\text { Hari } \\
\text { Ke 15 } \\
\text { (g) }\end{array}$ & $\begin{array}{c}\text { Berat } \\
\text { Badan } \\
\text { Hari } \\
\text { Ke 30 } \\
(\mathbf{g})\end{array}$ & $\begin{array}{c}\text { Penurunan } \\
\text { Berat } \\
\text { Badan } \\
(\mathbf{g})\end{array}$ & $\begin{array}{c}\text { Penurunan } \\
\text { Berat } \\
\text { Badan } \\
(\mathbf{\%})\end{array}$ \\
\hline $\begin{array}{l}\text { Kontrol } \\
\text { negatif }\end{array}$ & 32,75 & 33,39 & - & - \\
Kontrol & 35,05 & 38,00 & - & - \\
positif & & & & \\
Perlakuan 1 & 35,85 & 33,43 & 2,42 & $6,75 \pm 0,53^{\mathrm{a}}$ \\
Perlakuan 2 & 35,62 & 32,27 & 3,35 & $9,40 \pm 0,73^{\mathrm{b}}$ \\
Perlakuan 3 & 35,33 & 31,11 & 4,22 & $11,94 \pm 0,98^{\mathrm{c}}$ \\
\hline
\end{tabular}

Keterangan : notasi huruf yang berbeda menunjukkan beda nyata pada taraf $\%$

Pemberian soyghurt terhadap kelompok perlakuan (P1, P2, P3) menunjukkan persentase penurunan berat badan yang terendah sebesar $6,75 \pm 0,53 \%$ dan yang tertinggi sebesar $11,94 \pm 0,98 \%$. Penurunan berat badan ini disebabkan karena mencit diberikan soyghurt yang mengandung kedelai dengan kadar serat tinggi, sesuai dengan pernyataan Bell et al. (1990) yang melaporkan bahwa tingginya kandungan serat dalam makanan dapat mengurangi berat badan. bahwa kalsium dapat mengurangi kemampuan hormon kalsitriol yyang berfungsi untuk memberi tanda pada sel untuk menyimpan lemak. Makanan yang kaya akan kalisum akan mengurangi hormon kalsitriol dan mendorong penurunan berat badan.

\section{Pengukuran Kadar Kolesterol}

Waktu dan kelompok perlakuan untuk pengukuran kadar kolesterol seperti yang telah ditampilkan pada metode penelitian. Berdasarkan hasil uji statistik terhadap kadar kolesterol darah hewan uji (mencit) menunjukkan perbedaan kadar kolestrol $\mathrm{p}$ Perbedaan kadar kolesterol darah hewan uji terhadap masing-masing kelompok perlakuan dapat dilihat pada Tabel 4.6.

Tabel 4.6. Kadar Kolesterol Darah Mencit (mg/dl)

\begin{tabular}{lll}
\multicolumn{3}{c}{ Masing-Masing Kelompok Perlakuan } \\
\hline $\begin{array}{l}\text { Kelompok } \\
\text { Perlakuan }\end{array}$ & Rataan & Notasi \\
\hline Kontrol negatif & $57,74 \pm 4,24$ & $\mathrm{a}$ \\
Kontrol positif & $107,50 \pm 2,24$ & $\mathrm{~b}$ \\
Perlakuan 1 & $86,20 \pm 3,1$ & $\mathrm{c}$ \\
Perlakuan 2 & $76,40 \pm 5,42$ & $\mathrm{~d}$ \\
Perlakuan 3 & $63,70 \pm 3,11$ & $\mathrm{a}$ \\
\hline
\end{tabular}

Keterangan : notasi huruf yang berbeda menunjukkan beda nyata pada taraf $5 \%$ 
Kelompok kontrol negatif menunjukkan kadar kolesterol yang berbeda nyata $(\mathrm{P}<0,05)$ terhadap kelompok kontrol positif, P1, dan P2, dan berbeda tidak nyata $(\mathrm{P}>0,05)$ terhadap kelompok perlakuan $\mathrm{P} 3$. Hewan uji kelompok kontrol positif menunjukkan perbedaan kadar kolesterol yang berbeda nyata $(\mathrm{P}<0,05)$ terhadap kelompok perlakuan $\mathrm{P} 1, \mathrm{P} 2$, dan $\mathrm{P}$, sedangkan kelompok perlakuan P1 menunjukkan perbedaan kadar kolesterol yang berbeda nyata $(\mathrm{P}<0,05)$ dengan kelompok $\mathrm{P} 2$ dan $\mathrm{P} 3$, demikian juga dengan kelompok perlakuan P2 menunjukkan perbedaan kadar kolesterol yang berbeda nyata $(\mathrm{P}<0,05)$ dengan kelompok $\mathrm{P} 3$. Dari hasil kadar kolesterol rata-rata antara kelompok kontrol negatif dan kelompok kontrol positif, menunjukkan persentase peningkatan kadar kolesterol pada kelompok kontrol positif sebesar $86,18 \%$. Persentase peningkatan kadar kolesterol hewan uji (mencit) pada kelompok kontrol positif dapat dilihat pada Tabel 4.7.

Tabel 4.7. Persentase Peningkatan Kadar Kolesterol Darah Mencit pada Kelompok Kontrol Positif Pada Hari ke 15

\begin{tabular}{lccc}
\hline $\begin{array}{l}\text { Kelompok } \\
\text { Perlakuan }\end{array}$ & $\begin{array}{c}\text { Kadar } \\
\text { kolesterol } \\
(\mathbf{m g} / \mathbf{d l})\end{array}$ & $\begin{array}{c}\text { Peningkatan } \\
(\mathbf{m g} / \mathbf{d l})\end{array}$ & $\begin{array}{c}\text { Peningkatan } \\
(\mathbf{\%})\end{array}$ \\
\hline Kontrol & 57,74 & - & - \\
$\begin{array}{l}\text { Negatif } \\
\text { Kontrol }\end{array}$ & 107,50 & 57,76 & 86,18 \\
Positif & & & \\
\hline
\end{tabular}

Peningkatan kadar kolestrol pada hewan uji (mencit) kelompok kontrol positif, karena diberi pakan kolesterol tinggi selama 2 minggu. Pemberian pakan kolesterol tinggi, menyebabkan peningkatan jumlah jaringan lemak pada otot (adiposa) yang dapat menghasilkan jumlah kalori yang tinggi. Meningkatnya jumlah kalori yang tersimpan dalam jaringan lemak dan otot, akan meningkatkan kadar kolestrol dalam darah. (Pierre et al., 2000).

Tabel 4.8. Persentase Penurunan Kadar Kolesterol Darah Mencit Hari ke 30 Masing-Masing Kelompok Perlakuan

\begin{tabular}{lccc}
\hline $\begin{array}{l}\text { Kelompok } \\
\text { Perlakuan }\end{array}$ & $\begin{array}{c}\text { Kadar } \\
\text { Kolestrol } \\
(\mathbf{m g} / \mathbf{d l})\end{array}$ & $\begin{array}{c}\text { Penurunan } \\
(\mathbf{m g} / \mathbf{d l})\end{array}$ & $\begin{array}{c}\text { Penurunan } \\
(\mathbf{\%})\end{array}$ \\
\hline $\begin{array}{l}\text { Kontrol } \\
\text { negatif }\end{array}$ & 58,67 & - & - \\
Kontrol & 107,83 & - & - \\
positif & & & \\
Perlakuan 1 & 87,83 & 20,00 & $18,43^{\mathrm{a}}$ \\
Perlakuan 2 & 81,17 & 26,66 & $22,18^{\mathrm{a}}$ \\
Perlakuan 3 & 69.17 & 38,66 & $35,75^{\mathrm{a}}$ \\
\hline
\end{tabular}

Kelompok P1 yang diberi soyghurt 0,25\% menunjukkan persentase penurunan kadar kolesterol sebesar 18,43\%, kelompok P2 yang diberi soyghurt 0,5\% menunjukkan persentase penurunan kadar kolesterol sebesar 22,18\%, dan kelompok P3 yang diberi soyghurt
$1 \%$ menunjukkan persentase penurunan kadar kolesterol sebesar $35,75 \%$. Penurunan yang significan dari ke 3 kelompok perlakuan, ditunjukkan pada kelompok P3 yaitu pemberian soyghurt sebanyak $1 \%$ dengan penurunan kadar kolesterol sebasar 35,75\%. Penurunan kadar kolesterol tersebut karena soyghurt merupakan produk susu fermentasi. Sisa kolesterol dikeluarkan bersama feses (Poerwosoedamo dan Soedioetama, 1977), juga BAL memproduksi enzim Bile Salt Hydrolase (BSH) yang dapat mengurangi konjugasi garam empedu sehingga akan meningkatkan asam empedu bebas yang tidak mudah diserap oleh usus halus. Untuk menyetimbangkan jumlah asam empedu, dibutuhkan kolesterol dari dalam darah sehingga kadar kolesterol dapat diturunkan secara total (Lee dan Salminen, 2009).

Hasil pada penelitian ini membuktikan bahwa pemberian soyghurt yang dibuat dengan suhu inkubasi yang optimal $\left(40^{\circ} \mathrm{C}\right)$ dan jumlah koloni BAL yang optimal (163 CFU/ml), efektip menurunkan kadar kolesterol darah hewan uji (mencit) hingga $40,74 \%$ dengan konsentrasi soyghurt $1 \%$.

\section{SIMPULAN DAN SARAN}

\section{Simpulan}

Berdasarkan hasil penelitian yang telah dilakukan dapat diambil kesimpulan :

1. Dihasilkan suhu inkubasi yang optimal pada pembuatan soyghurt yaitu suhu $40^{\circ} \mathrm{C}$.

2. Diperoleh jumlah bakteri asam laktat pada suhu optimal sebesar $1,63 \times 10^{9} \mathrm{CFU} / \mathrm{ml}$.

3. Ditemukan 2 isolat pada soyghurt yang diidentifikasi sebagai Lactobacillusbugaricus dan Streptococcus thermophillus.

4. Bakteri asam laktat yang ditambahkan sebagai stater pada pembuatan soyghurt mampu menurunkan kadar kolesterol dalam darah mencit.

5. Konsentrasi soyghurt $1 \%$ menunjukkan persentase penurunan kadar kolesterol paling tinggi yaitu $35,75 \%$.

\section{Saran}

Perlu dilakukan penelitian lebih lanjut terhadap jumlah starter yang diberikan dalam pembuatan soyghurt untuk melihat seberapa besar efektifitasnya dalam menurunkan kadar kolesterol dalam darah, serta penambahan rasa dengan tidak mengurangi kemampuan bakteri asam laktat tersebut dalam menurunkan kadar kolesterol

\section{DAFTAR KEPUSTAKAAN}

Akalin, A.S., Gonc, S., and Duzel, S. 1997. Influence of yoghurt and Acidophillus yoghurt on serum cholesterol level in mice. Journal Dairy Science 80: 2721-2725

Animal Research. 2002. Blood collection and administration of fluids and drug (mouse). Institutional Animal Care and use Comitte the University of Towa. 
Barrow, G.I. and Kromosom, A. F. 1993. Cowan and steels manual for the indification of medical bacteria. Cambridge University Press, Great Britain.

Bell, L.P.K., Hectom., Reynolds,H., Hunninghake, D. 1990. Cholesterol-lowering effects of soluble-fiber as part a prudent diet for patients with mild to moderate hypercholesterolemia. Am.J. Clin. Nurt. 52(6): 1020-1026

Danielson, A.D., Peo, E.R., Jr., Shahani, K.M., Lewis, A.J., Whilen, P.J., and Amer, M.A. 1989. Anticholesteremic property of Lactobacillus acidophilus yoghurt fed to masture boars. Journal of Animal Science. 67 (46): 966-974.

Djide, N. 2006. Efek hipokolesterolemia kulturt bakteri asam laktat dalam soyghurt terhadap tikus putih. J. Sains \& Teknologi. 6 (1): 13-18.

Hasan, Z.H. 2006. Isolasi Lactobacillus, Bakteri asam laktat dari feses dan organ saluran pencernaa ayam. Seminar Nasional Teknologi Peternakan dan Veteriner.

Heller, J. K. 2001 Probiotic bacteria in fermented foods : Product characteristic and starter. American Journal of Clinical Nutrition 73 (2): 3748-3795.

Hidayat, N., M.C. Padaga, dan S. Suhartini. 2006. Mikrobiologi Idustri. Andi, Yogyakarta.
Jawetz, E. 1980. Review of Medical Microbiology. $11^{\text {th }}$ Edition, Lange Medical Publication, Los Altos

Koswara, S. 2006. Susu kedelai tak kalah dengan susu sapi. e book pangan.com

Kurana, H.K. 2007. Resent trends in development of fermented milks. Current Nutrition \& Food Science 3: $91-108$

Lay, B.W. 1994. Analisis Mikrobiologi di Laboratorium . Raja Grafindo Persada, Jakarta.

Ooi, Lay-Gaik., Ling, and Min-Tze. 2010. Cholesterol lowering effect of probiotics and prebiotics : A Review of in Vivo and in Vitro fnding. Int. Mol.Sci $11: 2499-2522$.

Poerwosoedamo dan Sediaoetama, A.D. 1977. Ilmu Gizi. Penerbit. Dian Rakyat Jakarta. Hal 254.

Soeharsono. 2010. Probiotik. Basis Ilmiah Aplikasi Dan Aspek Praktis. Widya Padjadjaran. Bandung.

Suriawiria, U. 2005. Mikrobiologi Dasar. Penerbit Papas Sinar Sakti. Jakarta..

Yudhi, 2008. Penelitian Soyghurt. File:///g:/penelitian soyghurt.htm. (Diakses tanggal 15 Maret 2011).

Zahoor, T., S.U., Rahman., Umar, F., and Farooq. 2003. Viability of Lactobacillus bulgaricus on yoghurt culture under different preservation methods. Departemen of food Technologi and Veterenary Microbiology. 5 (1): 38-43. 